Monika Buława

Instytut Języka Polskiego Polskiej Akademii Nauk, Kraków

e-mail: monika.bulawa@ijp-pan.krakow.pl

\title{
NAZWY CHORÓB EPIDEMICZNYCH W PRZEKLĘCIACH GWAROWYCH
}

Słowa klucze: leksyka gwarowa, nazwy chorób, przeklęcia

Keywords: dialectal vocabulary, names of illnesses, curses

Opisując zawartość treściową formuł przeklęć, Anna Engelking (2010) wyróżniła trzy grupy zjawisk, które w tego rodzaju wypowiedziach przywołuje nadawca jako karę dla osoby przeklętej, są to: choroba, śmierć i niedola. W swojej monografii poświęconej ludowym rytuałom klątwy autorka przytacza obszerny zbiór formuł będących życzeniem choroby, wśród nich zaś grupę takich, w których występuje nazwa konkretnego schorzenia.

Ta właśnie kategoria przeklęć będzie przedmiotem mojego zainteresowania w niniejszym artykule. Wykorzystany w nim materiał pochodzi z kartoteki Słownika gwar polskich PAN (SGP), a zebrany został w trakcie kwerendy związanej z moimi badaniami nad gwarowymi nazwami chorób. Takie ukierunkowanie poszukiwań materiałowych - na nazwy, nie zaś bezpośrednio na przeklęcia - pozwoliło dotrzeć do sporej ich liczby, w tym zawierających mniej oczywiste nazwy, takie jak pomucha czy wąsiel.

Omówienie wszystkich zgromadzonych przeklęć oraz użytych w nich nazw znacznie przekroczyłoby dopuszczalne ramy artykułu. Dlatego też po ogólnym przedstawieniu, jakie nazwy chorób wystąpiły w zebranym materiale, skupię się na analizie tylko jednej ich grupy. Moim zamiarem jest pokazanie przeklęć z nazwami chorób epidemicznych w szerszym kontekście językowym, uwzględniającym funkcjonowanie danej nazwy w gwarach - nie tylko w jej podstawowej roli nazwy choroby, 
ale także jako komponentu związków frazeologicznych oraz jednostki podlegającej procesom derywacji semantycznej i słowotwórczej.

$\mathrm{W}$ artykule będę się posługiwać terminem przeklęcie na określenie formuły słownej zawierającej życzenie złego losu (Engelking 2010: 105). Jego zaletą jest jednoznaczność, której nie ma synonimiczny wyraz przekleństwo ${ }^{1}$. Aby uściślić, jakiego typu jednostki językowe będę brała pod uwagę, chciałabym odwołać się do eksplikacji Macieja Grochowskiego (1991: 6), który w następujący sposób eksplikuje zwrot: X RZUCA PRZEKLEŃSTWO NA Y-a:

'X myśląc o Y-u, chce, żeby Y-owi stało się coś złego;

$\mathrm{X}$ sądząc, że może to spowodować mówiąc,

mówi: niech Y-owi stanie się coś złego'.

Genetycznie przeklęcia związane były z myśleniem magicznym, zgodnie z którym możliwe jest wywołanie pewnych zmian w rzeczywistości poprzez wypowiadane słowa (Engelking 2010). Później zaczęły funkcjonować jedynie jako wyraz negatywnych emocji nadawcy. Przyjmuję jednak, że jeśli zostaje wyrażona formuła 'niech Y-owi stanie się coś złego', nadal mamy do czynienia z przeklęciem, nawet jeśli nie jest ona motywowana wiarą w możliwość wpływania w ten sposób na rzeczywistość.

Obiektem przeklęcia $\mathrm{w}$ analizowanych wypowiedziach bywał najczęściej odbiorca, np. Żeby cie laksyrka ['biegunka'] napotkała (tarnob MPTL XXVI: 288), lub osoba trzecia, np. A niech go ta gangryna udusi! (łęcz PJPAN 37: 241), sporadycznie sam nadawca: Bogdaj mnie morówka zabiła! (Mp pd-wsch ME XI: 267). Negatywne emocje mogą być jednak także ukierunkowane nie ku osobie, lecz ku jakiejś rzeczy, sytuacji, np. A niech to paralusz weźmnie! (Koc SKoc III: 18).

W konstrukcji związków będących w tym artykule obiektem analizy można wyróżnić następujące elementy²: 1) wykładnik trybu rozkazującego bądź życzącego, np. niech, żeby, oby, bodaj; 2) człon nominalny w bierniku, np. to, was, to wszystko, ich, cię; 3) człon pełniący funkcję wzmacniającą, np. jasna; 4) człon werbalny, np. cholera wzięła, szlag trafit (Przybylska 1986: 349). W realizacjach tej formuły możliwe jest zarówno pomijanie pewnych składników (m.in. z członu werbalnego może zostać usunięty czasownik, np. żeby cię cholera), jak i rozbudowywanie jej o dodatkowe elementy (np. Niech jego pomorek weźnie z tako roboto! (Huszcza bial-podl), Żeby cie szlak trafit w samo serce (tarnob MPTL XXVI: 288)).

1 Przekleństwo w języku ogólnym to zarówno 'obelżywe, wulgarne wyrazy używane w stosunku do kogoś lub dla wyrażenia gniewu, złości', jak i 'wyrażone przez kogoś życzenie komuś złego losu, nieszczęścia, klęski itp.; klątwa’ (SJPSz II: 978).

2 Spośród przedstawionych w artykule przeklęć w schemacie tym nie mieszczą się tylko dwie jednostki: Boże dopomóż, aby go ciężki szlak trafił oraz pomorek na niego. Jak podkreśla A. Engelking (2010: 237), przeklęciami mogą być też wypowiedzenia o nietypowej strukturze, innej niż tu przedstawiona (np. zdanie przypuszczające: Wolałabym cię $w$ trumnie widzieć niż z nia przy ołtarzu) - funkcja formuły jest w tym wypadku istotniejsza niż jej budowa. 
Jak już wspomniałam, analizowany w artykule materiał wyekscerpowany został z kartoteki SGP, a zatem jest on zróżnicowany terytorialnie (pochodzi z całego polskiego obszaru dialektalnego) oraz chronologicznie (XIX-XX w.), także pod względem swojego charakteru (kilka przeklęć zostało wyekscerpowanych z tekstów folkloru, głównie pieśni). W większości był to materiał rozproszony po wielu źródłach drukowanych i rękopiśmiennych. Wykorzystałam jednak również dwa zbiorki: zawierającą 91 pozycji „litaniję przekleństw, jakiemi się obrzucano”, zamieszczoną w Łęczyckiem Oskara Kolberga (Łęcz: 10-12) oraz „przekleństwa dawne” zebrane z Rozwadowa i okolic (MPTL XXVI: 287-289).

Na danych $z$ kartoteki SGP opiera się także przedstawiony przeze mnie opis funkcjonowania w gwarach danego leksemu. Kartoteka ta, gromadząca ok. dwóch i pół miliona fiszek oraz dokumentująca ok. 240 tysięcy haseł, pozwala na prowadzenie badań leksykalnych obejmujących wszystkie polskie dialekty, także w zakresie starszej warstwy słownictwa, mającej już charakter historyczny. Należy jednak zastrzec, że nie zawsze zawarte w niej materiały informują o dokładnym zasięgu geograficznym danego leksemu; brak poświadczenia danej jednostki w kartotece nie musi zatem oznaczać, że nie występuje czy też nie występowała ona na określonym terenie.

Wszystkie cytaty przytaczam w zapisie ortograficznym, rozszerzonym jedynie o dodatkowe znaki dla $e$ oraz a pochylonego. Lokalizację geograficzną podaję zgodnie z zasadami praktykowanymi w SGP (zob. SGP I: LII). Jeśli materiał pochodzi ze źródła drukowanego, po skrócie nazwy powiatu (ewentualnie innego oznaczenia geograficznego) umieszczony zostaje skrót tytułu danego źródła. W wypadku materiałów rękopiśmiennych skrót nazwy powiatu podawany jest po nazwie wsi.

Nim przejdę do omówienia interesujących mnie jednostek, trzeba podkreślić, że życzenie choroby nie musi być realizowane z posłużeniem się nazwą konkretnego schorzenia. Po pierwsze, życzyć można komuś ogólnie choroby, bez precyzowania, o jaką chodzi, np. Żeby cię choroba utłukła!'s (Sand: 246); Bodaj cię trzy choroby uttukły! (Lub I: 26); Żebyś łodchorowat (MPTL XXVI: 288). Po drugie zaś - można wyrażać w sposób opisowy to, co ma się przydarzyć człowiekowi będącemu obiektem przeklęcia, np. Ażeby ci kości pogruchotało (Łęcz: 11); Bodaj ci się kiszki powykręcały (Łęcz: 11); Bodaj ci wątroba spuchta! (Kuj I: 52).

W zebranym przeze mnie zbiorze przeklęć zostały użyte 22 nazwy chorób lub ich objawów. Najliczniej reprezentowane były następujące jednostki:

- nazwy chorób epidemicznych (omówione poniżej);

- nazwy febry (febra, ograżka, zimnica, zimno), np. A niech go frybra weźnie (łęcz PJPAN 37: 213); Niech ich tam ograska! (Krp LL V: 104); Bodaj cię zimno trzęsło (ok. Krakowa Krak III: 163);

3 A. Engelking (2010: 259) w podobnym przeklęciu Ażeby cię choroba tłukła od nieba do ziemi (Łęcz: 11) interpretuje leksem choroba jako nazwę padaczki. Wspominam o tej możliwości interpretacyjnej, przyjmując, że trudno w wypadku przywołanych przeklęć o jednoznaczne rozstrzygnięcie, czy wyraz choroba funkcjonuje w nich jako hiperonim, czy też nazwa epilepsji.

4 Zapis za źródłem. 
- paraliż (w różnych gwarowych realizacjach), np. Żeby wás paraliż chyciuł (Górka brzoz); Niech go paralus ruszy (zam PF IV: 229); Bodaj cie paralus narusył (radz-podl Pleszcz: 105); A niech to paralusz weźmnie! (Koc SKoc III: 18);

- szlag ${ }^{5}$, np. Bodej cie ślak trafiut (wad RWF IX: 215); Żeby cie szlak trafit w samo serce (tarnob MPTL XXVI: 288); Boże dopomóż, aby go ciężki szlak trafit (tarnob MPTL XXVI: 289);

- kolka, np. Zeby cie kolka wziéna (Janki Młode ostroł); Bodaj ju kolky sperły! (płoc WMal: 20); Wędrowała Zosia przez dziewiéńć miesięcy. / Niech go kolka skole, już go nie chce więcy (z pieśni, ok. Łańcuta ME VI: 304).

Inne nazwy chorób, które zostały użyte w przeklęciach, to: padaczka, wielka choroba 'padaczka', gangrena, kołtun, lakserka, wrzód, morzyska 'bóle w jamie brzusznej', wasiel ${ }^{6}$, np. Bodaj cie padacka wziena (tarnob MPTL XXVI: 288); Bodej cie morzyska wzieny (tarnob Wisła X: 742); Bo(g)daj cie wassiel tracit (zam PF V: 926).

Wśród nazw chorób epidemicznych ${ }^{7}$ znalazły się następujące jednostki:

- powietrze: Niech cie powietrze weźnie (Degucie suw); Bodaj cię powietrze (Piszczac bial-podl);

- morówka: Bogdaj mnie morówka zabiła! (Mp pd-wsch ME XI: 267); Żeby cie morówka (Kuj PF IV: 218);

- pomór: A niech je ta pomór podusi! (łęcz PJPAN 47: 7968);

- pomorek: Niech jego pomorek weźnie z tako roboto! (Huszcza bial-podl); A żeb ciebie pomorek (Horodyszcze włod); Pomorek na niego (Baciki Średnie siem);

- dżuma (forma: ciuma): A bodaj cię ciuma wziena, / Że ja poszła za Rusina (z pieśni, Ponikwoda-Lublin, Skrz: 57);

- pomucha: To stary Sima ji tén Zólty Mosiek go namówiéły ji já sie dałém tak zgłupić! Zeby téch parchów pomucha wybrała! Bodej óny nie dockały! (tarnob LL XIX: 49);

- cholera: Zeby cię cholera zabiła (największe przekleństwo, rzadko u włościan koło samych Kielc używane) (ok. Kielc Zb II: 257); Ażeby cię cholera spotkała (łęcz Łęcz: 11); Żeby cie (jasna) cholera wzięła (tarnob MPTL XXVI: 288); A jego jaśnista

5 W cytatach zachowuję zapis szlak, jest to bowiem jedna z postaci, w jakich leksem ten funkcjonował w gwarach (a także w dawniejszej polszczyźnie).

6 Formę tę interpretuję jako przekształconą nazwę wąsad 'ból w krzyżu', zapewne w wyniku adideacji (skojarzenia z leksemem wąsiel 'gąsienica').

7 Niektóre z podanych nazw notowane są w słownikach także w znaczeniu 'epidemia', a więc nie jako nazwa choroby zakaźnej, lecz zjawiska polegającego na masowym jej występowaniu. Ścisłe odgraniczenie tych dwóch znaczeń nie zawsze jest jednak możliwe w odniesieniu do materiałów gwarowych.

8 W źródle pomór zdefiniowany jako 'choroba świń'.

9 W kontekście poruszanej w tym artykule problematyki nie można nie wspomnieć, że pierwotnie leksem parch, użyty tutaj jako pogardliwe określenie Żydów, to nazwa choroby. W gwarach i w dawniejszej polszczyźnie służył on do nazywania schorzenia, które obecnie nosi miano grzybicy woszczynowej, a także innych chorób skórnych. 
cholera żeb wzieła (Degucie suw) (por. też kasz Niech wąm jabel ['diabeł'] cholere przeniese [przyniesie]! (Derd: 47$)$.

Odwoływanie się w przeklęciach do chorób epidemicznych znajduje uzasadnienie $\mathrm{w}$ tym, że były to choroby powodujące dużą śmiertelność i wzbudzające lęk ${ }^{10}$. W niektórych wypadkach posłużenie się ich nazwami stanowiło złamanie tabu, co dodatkowo mogło wzmacniać nadzieję nadawcy na realizację jego życzenia. W odniesieniu do leksemu cholera Andrzej Bańkowski zwraca uwagę na inny jeszcze czynnik: „wybitną eufonię słowa” (SEBań I: 142), której to jego zdaniem przypisać należy szybkie upowszechnienie się tego wyrazu w przekleństwach.

Spośród nazw użytych w przywołanych wyżej formułach najstarszym określeniem choroby epidemicznej jest powietrze, zaliczające się do grupy nazw chorób motywowanych etiologią, to znaczy przekonaniami na temat ich pochodzenia (por. „Powietrze morowe jest plaga boża, mówią, iż jest para niejaka jadowita, z powietrzem pomieszana, duchowi żyjącemu nieprzyjazna" (SL IV: 424)). SStp (VI: 521) w znaczeniu 'zaraza, mór, pestis' odnotowuje wyrażenia: morowe, złe powietrze. Później w takim znaczeniu leksem ten występował także bez określających go przymiotników (SPXVI XXIX: 158-159; SL IV: 424; SW IV: 848). Słowniki rejestrują go również jako komponent przeklęć: Bodajże tak złych panów powietrze porwało (SL IV: 424); bodaj, żeby cię (go, was, ich) morowe (powietrze wydusiło) (SJPD IV: 841).

Powietrze nie jest zatem w gwarach nazwą dyferencyjną; ludności wiejskiej mogła być ona znana choćby dzięki śpiewanym w kościołach Suplikacjom („Od powietrza, głodu, ognia i wojny zachowaj nas, Panie”). W kartotece SGP leksem powietrze $\mathrm{w}$ interesującym mnie znaczeniu poświadczony jest jedynie kilkakrotnie; $\mathrm{w}$ kilkunastu innych poświadczeniach wyraz ten występuje ponadto $\mathrm{z}$ określającym go przymiotnikiem, przede wszystkim morowy (morowe powietrze). Poza tym został on odnotowany jako komponent frazeologizmów: do powietrza (Daj mnie spokój, do pohietrza (Janki Młode ostroł)), od powietrza (Co tyż ta za bydlok od powietrzo (Kramsk koniń)), od morowego powietrza"1 (A to od morowego powietrza! (Kuj Kuj I: 52)). Funkcję wyrażania negatywnych emocji pełnią również jednostki związane słowotwórczo z leksemem powietrze, używane jako wyzwiska: powietrzny (A to powietrzny! Kuj Kuj I: 52, To drań, małpa, pohietrzna suka, wszystke mléko wylała (o kotce) (Janki Młode ostroł); też: opocz RWF XI: 187; (Adamowo mław), powietrz-

10 Obszerny obraz ludowego pojmowania chorób epidemicznych przedstawiła w ujęciu etnolingwistycznym Marzena Marczewska (2012: 151-186).

11 Por. od morowego powietrza 'zły, od siedmiu boleści, Boże polituj, marny, niemożliwy, straszny, nieznośny, obrzydliwy’: Koncert od morowego powietrza (SW II: 1043). 
nik (Wąworków opat; Janki Młode ostroł), powietrznica (Giełczew kras; Janki Młode ostroł), a także zadiektywizowany imiesłów bierny czasownika zapowietrzyć - zapowietrzony (Ty draniu zapowietrzóny Brudzewice opocz; też: opocz RWF XI: 187; łęcz PJPAN 72: 1155; Złotniki kal; Kramsk koniń) ${ }^{12}$.

$\mathrm{W}$ zebranym przeze mnie materiale znalazło się także przeklęcie $\mathrm{z}$ komponentem powietrze, którego intepretacja nie jest jednoznaczna: A bodaj cię powietrze raziło (łęcz Łęcz: 11). A. Engelking (2010: 258) przytacza tę frazę jako odnoszącą się do zarazy. Brałabym jednak pod uwagę, że może tu chodzić o inną - równie popularną w przeklęciach - chorobę, a mianowicie paraliż. W wypadku tej drugiej interpretacji również trzeba odwołać się do dawnej wiedzy medycznej i właściwych jej przekonań etiologicznych, zgodnie z którymi powietrze było czynnikiem odpowiedzialnym za powstanie paraliżu. Podobne pojmowanie przyczyn tej choroby spotykamy również w medycynie ludowej, np. „Lud mniema, że [paraliż] pochodzi z zawiania podczas przeciągu powietrza przez otwarte na oścież drzwi i okna, a głównie przez wicher, tj. trąbę powietrzną" (Wisła XI: 778). Wspomniane przekonania etiologiczne uzasadniają funkcjonowanie $\mathrm{w}$ dawnej polszczyźnie (w odniesieniu do paraliżu i apopleksji $\left.{ }^{13}\right)$ takich połączeń, jak: powietrzem ruszony, (być) trącon(y); powietrza ruszenie; powietrze ruszy(to) [kogo]; powietrza zabicie; powietrzem zabity; powietrze zabije [kogo]; powietrzem (jest) zarażon(y); powietrza, powietrzem zarażenie; powietrze zaraziło (SPXVI XXIX: 158) (por. też połączenia użyte w SW (VIII: 336) w definicji zwrotu zawiać kogo 'zarazić powietrzem, razić, ruszyć powietrzem, tknąć powietrzem, zaciągnąć przeciągiem, sparaliżować). Również w materiale gwarowym odnotowałam kolokację powietrze razi w odniesieniu do paraliżu: Powietrze człowieka razi, ni mo władzy (tor MacSł: 178). Jako materiał porównawczy warto jeszcze przywołać podobne przeklęcie odnotowane w XVII-wiecznym kazaniu: Bogdaj cię powietrze ruszyło ${ }^{14}$ (Gdacjusz 1969: 159).

Kolejne trzy nazwy, które zostały użyte w przedstawionych wyżej przeklęciach morówka, pomór i pomorek, powiązane są słowotwórczo z leksemem mór (SStp IV: 347, z psł. rz. ${ }^{*}$ morø, pochodnego od cz. ${ }^{*} m e r t i$ 'umierać' (ЭССЯ XIX: 250)).

Morówka 'morowa zaraza' odnotowana została w SJPD (XI: 305) z kwalifikatorem „rzadko używany”, w SW (II: 1056) - jako jednostka staropolska i gwarowa. Znaczenie to podaje Słownik łacińsko-polski Bartłomieja z Bydgoszczy (1532 r.): Pestilentia,

12 W sprawdzonych źródłach leksykograficznych (SStp, SPXVI, ESJPXVII-XVIII, SL, SW, SJPD, SJPSz, USJP, PSWP) w omawianych znaczeniach przenośnych odnotowane zostały wyrazy powietrzny (SW IV: 849) oraz zapowietrzony (SW VIII: 230; SJPD X: 709), jednak tylko jako jednostki gwarowe. Przykłady użycia leksemu zapowietrzony można ponadto znaleźć w NKJP (m.in. z dzieł Władysława Reymonta i Andrzeja Sapkowskiego).

13 Apopleksja, czyli wylew krwi do mózgu, mogła powodować paraliż. Połączenia z SPXVI podaję łącznie, nie precyzując, które odnoszą się do paraliżu, które zaś do apopleksji.

14 Łaciński dopisek na marginesie tekstu wskazuje, że chodziło w tym wypadku właśnie o paraliż. 
morowka, pestis, povyetrzne zarazenye (za: SPXVI XV: 12) (powołując się na to samo źródło, $z$ definicją 'pestis, pestilentia' ['zaraza, dżuma'], zamieszcza morówkę PSL I: 467). W mianownictwie lekarskim omawiany leksem funkcjonował także w innych znaczeniach, między innymi jako nazwa charakterystycznego objawu dżumy, czyli bolesnego obrzmienia, a później zropienia węzłów chłonnych (SPXVI XV: 12; SL III: 158; SW II: 1043; PSL I: 467).

W kartotece SGP morówka jako nazwa choroby epidemicznej poświadczona jest w trzech wsiach małopolskich ('cholera' Przedmość wiel; 'zaraza': Na bydło beła morówka Dąbrowa Poduchowna iłż, Na morówke to tyz tako pryntko śmierć Woźniki sier ${ }^{15}$ ), ponadto $\mathrm{w}$ powiecie tureckim jako nazwa nosacizny (choroby zakaźnej koni) (tur PJPAN 48: 57); w znaczeniu 'morowa zaraza' rejestruje ją także Sychta z gwar kaszubskich (SGK III: 106). Poza tym morówka została odnotowana w gwarach jako element frazeologizmów wariantywnych $\mathrm{w}$ stosunku do związków wyrazowych z komponentem 'diabeł': idź do morówki! (Kuj Kuj I: 52); jak sto morówek (inow SobKuj: 73); do morówki ciężkiej (Naschodzi sie na zobawe do morówki cinżki i zaś sie bijom (Kramsk koniń)).

Warto dodać, że w celach stylizacyjnych przeklęcia $\mathrm{z}$ omawianym tu leksemem wprowadzał do swoich utworów Władysław Reymont: „Żeby to morówka wziena, psiakrew!”; „Żeby ich morówka zdusiła!”; „[...] niech się ta kłyźnią i zagryzają, takie nam braty jedne i drugie, że niechta ich morówka nie minie” (Chłopi); „Żeby was, psiekrwie, wydusiła morówka!" (Rok 1794) ${ }^{16}$.

O wiele liczniej w znaczeniu 'zaraza' poświadczone są dwa następne leksemy, czyli pomór i pomorek. SPXVI (XXVII: 175) rejestruje jedynie deminutiwum. Formę pomor (jednak bez cytatów) podaje SL (IV: 328). SEBań (II: 695) jako pierwsze poświadczenie leksemu pomór przywołuje Słownik dokładny języka polskiego i niemieckiego Bandtkiego z 1806 r. Również SEBor (s. 462) opisuje ten leksem jako funkcjonujący w polszczyźnie od XIX w. Według Wiesława Borysia późne poświadczenie leksemu oraz geografia wyrazu gwarowego pomorek (z Tykocina i okolic Przasnysza) wskazują na zapożyczenie z języków wschodniosłowiańskich. Jako materiał porównawczy podaje następujące jednostki: ukr. помір 'śmiertelna choroba, zaraza, mór', br. przest. i dial. nаморак 'mór, zaraza', dial. też naмор 'ts.' (od psł. cz. * pomerti 'zemrzeć) (SEBor: 462).

SPXVI (XXVII: 175) notuje pomorek w znaczeniu 'morowe powietrze, epidemia'. Przykłady pochodzące z XVII (słownik Knapiusza) oraz XVIII w. podaje SL (IV: 328). SW (IV: 574) poszerza te poświadczenia o cytat z Karola Szajnochy. SJPD (VI: 953) rejestruje pomorek jako wyraz dawny, z definicją 'choroba zakaźna, epidemia (głównie zwierząt); pomór'.

15 W źródle podana definicja 'rodzaj choroby'; o tym, że chodzi o groźną chorobę epidemiczną, wnioskować można z cytatu. W gwarach morówka występowała także w innych znaczeniach „medycznych”, które tutaj pomijam.

16

Materiał uzyskany z NKJP. 
Przytoczone wyżej przeklęcia z leksemem pomorek zostały odnotowane w gwarach wschodnich (bial-podl, włod, siem). Jedno z nich stanowiło realizację nietypowego - w kontekście innych formuł - schematu składniowego: pomorek na kogośl coś. Inne zebrane przeze mnie przykłady realizacji tego schematu pochodzą z utworów Henryka Sienkiewicza: Pomorek na taka pogodę! (1986: 49); Pomorek na jego potomstwo! (ibid.: 246); Pomorek na ciebie, piekielne bydlę! (Sienkiewicz 1978: 342).

Kartoteka SGP potwierdza obecność leksemu pomorek przede wszystkim w gwarach wschodnich. Leksem ten odnotowany został nie tylko w przedstawionym wyżej znaczeniu (ok. Przasnysza SKJ VG: 119; wys-maz PF IV; 860; wys-maz DwZw: 163; Sławatycze włod; dęb Lud XII: 76; b.l. Wisła XV: 8o), ale także jako komponent związków wariantywnych w stosunku do frazeologizmów z komponentem 'diabeł' (Coż ty babo! pomorek cie ma wzią́s czy co? (Strupień chłm); Te dzieci brudne jak pomorki! (Huszcza bial-podl)), jako nazwa człowieka pod jakimś względem negatywnie ocenianego ('człowiek nieznośny' (ok. Przasnysza SKJ VG: 119); 'zabiedzony człowiek' (raw-maz RŁTN XXVI: 244)) oraz w funkcji wyzwiska („W uniesieniu wołają: »Podrago, potłumku wiary chrześcjańskiej, Judasu, odscepieńce, pomorku, chorobo, cholero [...]«" (radz-podl Pleszcz: 105)); pomorek - coś w rodzaju ty cholero (Baciki Średnie siem)).

Liczniej i ze wszystkich dialektów polskich w kartotece SGP poświadczony jest leksem pomór ${ }^{17}$. SW notuje ten wyraz w ogólnym znaczeniu zarazy, epidemii (w odniesieniu do ludzi i do bydła), a także jako nazwę konkretnej choroby: moru (SW IV: 574, 576) ponadto jako człon wyrażenia pomór wschodni (SW I: 586). SJPD (VI: 953) oprócz definicji 'masowe umieranie, padanie (zwykle wskutek chorób zakaźnych); epidemia, zaraza, mór' rejestruje znaczenie 'ostra choroba zakaźna świń, kur i indyków, wywołana przez wirus przesączalny’.

Znaczenia leksemu pomór w gwarach nie odbiegają - z drobnymi wyjątkami - od podanych wyżej znaczeń, przy czym większość poświadczeń odnosi się do chorób zwierząt, przede wszystkim świń i kur. W źródle, z którego pochodzi przywołane przeklęcie: A niech je ta pomór podusi! (łęcz PJPAN 47: 796), pomór zdefiniowany został jako 'choroba świń. Użyta forma zaimka ( $j e$ ) dopuszczałaby interpretację, że przeklęcie to zostało sformułowane nie w odniesieniu do ludzi, lecz zwierząt. Oczywiście ta pierwsza możliwość też nie jest wykluczona.

Dżuma, obecnie oficjalna nazwa choroby, którą dawniej określano mianem moru, to jednostka, która w nomenklaturze medycznej pojawiła się dopiero w XIX w. Etymologia wyrazu nie jest jasna (SESł I: 214; SEBań I: 337). Według SESł w polszczyźnie wyraz ten stanowi zapożyczenie z języka ukraińskiego (ukr. чумa, джумa).

Słowniki języka polskiego poza obecnie używaną formą dżuma (SW I: 669; SWil I: 289; SJPD II: 636) podają także warianty czuma (SW (I: 669) jako rzadko używane; SWil I: 201) oraz cuma (ibid. - w obu słownikach oznaczona jako forma błędna).

17 Najskromniej reprezentowany - zaledwie dwoma poświadczeniami - był dialekt śląski. 
W kartotece SGP leksem dżuma nie ma wielu poświadczeń, przy czym jedno z nich odnosi się do bliżej nieokreślonej choroby, z której powodu wyginęły w okolicy raki (zob. SGP VII: 341). Poza ogólnopolską postacią dżuma leksem ten został też odnotowany w formach fonetycznych: ciuma, dziuma, czuma (ibid.).

W gwarach omawiany wyraz funkcjonował jako nazwa nie tylko choroby, ale również jej personifikacji18: „Moja matka opowiadała, że pośle cholerycnej choroby chodziła ciuma” (suw PorJ 1956: 74); „W dawnech casach chodziła sobie po śwecie dziuma (inni: ciuma)” (wys-maz DwZw: 163); „»Dziuma« miała także jakoby odmieniać noworodków" (wys-maz DwZw: 163). Używano go ponadto jako wyzwiska: „[...] larwo, cumo, wiedźmo" (radz-podl Pleszcz: 105) ${ }^{19}$.

Forma ciuma, użyta m.in. w przywołanym wyżej przeklęciu, została odnotowana w gwarach, na które oddziałują języki wschodniosłowiańskie (Ponikwoda-Lublin PF IV: 189; wys-maz DwZw: 163; suw PorJ 1956: 74), co pozwala interpretować ją jako zapożyczenie (por. ukr. чума, ros. чума, br. чума). W wypadku frazy A bodaj cie ciuma wziena ze względu na geografię (Ponikwoda-Lublin) w grę wchodzić może wpływ języka ukraińskiego. Dlatego jako materiał porównawczy warto przywołać ukraińskie przeklęcie z leksemem чума: А щзб на вас чума напала (Гр. IV: 477).

Pomuchę jako nazwę zarazy odnotowuje SL (IV: 331) (z cytatem: „Pomucha padła na bydło"); słownik ten pokazuje ponadto przenośne użycia tego leksemu z poezji Wacława Potockiego (np. „Dziś na wszystek świat ta pomucha padła, Że choćby serce na łańcuchu wodzić, Byle prywacie małżeństwem dogodzić”). W. Boryś (1992: 163) pomuchę w tekstach Potockiego określa jako ,jeden z dialektyzmów gwary podkarpackiej utrwalonych przez tego pisarza". SW (IV: 579) zasadniczo powiela hasło z SL, poszerzając je tylko o dodatkowy cytat $z$ Potockiego.

W. Boryś, przedstawiając propozycję etymologii rzeczownika pomucha, pokazuje możliwość objaśniania go jako derywatu odczasownikowego, na co wskazuje jego struktura (przedrostek po-), co jednak trudne jest do udowodnienia ze względu na brak w materiale słowiańskim czasownika, który można by uznać za podstawę derywacyjną. Zgodnie z tą interpretacją rekonstruowany rzeczownik ${ }^{*}$ pomzcha (oraz jego ewentualny wariant pomøchø) byłby pierwotnie nazwą czynności z przypuszczalnym znaczeniem 'pokrycie czegoś (np. roślin) pleśnią, podobnym do pleśni nalotem’. Pierwszym etapem rozwoju semantycznego byłoby wytworzenie się wtórnych, konkretnych znaczeń, istniejących w gwarach rosyjskich: 'opary, mgła, rosa osiadające na roślinach (w postaci nalotu, osadu) i porażające je', 'nalot, osad na roślinach',

18 Por. dżuma 'ruska dziewica moru, mająca te same własności, co sławońska Kruga' (SWil I: 289).

19 Por. ukr. dial. чума ходяча [dżuma chodząca] 1) 'лайливий вислів' ['wyrażenie obraźliwe']; 2) 'дуже худа людина' ['bardzo chudy człowiek'] (ФСССГД: 533), чума болотяна (болотна) [dżuma bagienna] 1) ‘зла, вредна людина' ['zły człowiek']; 2) ‘брудна людина' ['brudny czlowiek'] (ibid.). 
z których z kolei rozwinęły się znaczenia 'zaraza roślinna' i 'zaraza zwierzęca'. Formę pomucha (zamiast * pomcha, w którą powinna się rozwinąc * pomzcha) wyjaśnia Boryś wstawieniem wtórnego -u-, być może w wyniku skojarzenia z rzeczownikiem mucha, nie wykluczając jednak, że jest to rezultat starej oboczności rdzennych samogłosek -r- : -u- (Boryś 1992: 165-166).

Pomucha należy do licznego zbioru gwarowych reliktów leksykalnych, dawnych wyrazów, które nie zachowały się w polszczyźnie ogólnej, dłużej natomiast przetrwały w języku mieszkańców wsi. W kartotece SGP leksem ten poświadczony jest ze Śląska Cieszyńskiego (Jaworzynka ciesz; Kozakowice ciesz; ciesz RWTN III: 102), Podhala (ME IX: 213; SKJ VD: 397), Orawy (KąśSGO II: 113), a także innych obszarów Małopolski południowej (Hyżne rzesz; myślen; krak PJPAN 11: 83; tarnob LL XIX: 37). W gwarach pomucha oznacza przede wszystkim zarazę dotykającą zwierzęta (kury, bydło, świnie, owce, także owady), rzadsze są poświadczenia użyć odnoszących się do ludzi, przy czym w jednym ze źródeł (PJPAN 11: 83) potraktowane zostały one jako przenośne. Zwraca uwagę, że we wszystkich cytatach podanych w źródłach leksem pomucha występuje wyłącznie we frazie przyszła pomucha (na coś, na kogoś), np. „Przyszła pomucha na kury” (Hyżne rzesz); „Taka latoś pomucha przysła, co sytka we wsi przenimagajom" (n-tar SKJ VD: 397).

W gwarach zostały odnotowane także przenośne użycia omawianego leksemu: „Taka przysła pomucha na Jaśka, co sie przecie latoś ozenił” (n-tar SKJ VD: 397); „A tém u starégo dziedzica béł za leśnégo taki jakisić Gola. Pono to béł Cech, ale to béła całá pomucha" (tarnob LL XIX: 37). W drugim cytacie po raz kolejny mamy do czynienia z posłużeniem się nazwą choroby jako określeniem człowieka negatywnie ocenianego.

Leksem cholera, nazywający niebezpieczną chorobę zakaźną, przebiegającą z gwałtownymi biegunkami i wymiotami, upowszechnił się w przeklęciach oraz innego rodzaju frazeologizmach służących do wyrażania negatywnych emocji w XIX w. (SEBań I: 142). SL nie notuje jeszcze przeklęć z tym leksemem; rejestruje je natomiast SW (I: 290, gm.: A żeby cię cholera wzięła!).

Według SESł (II: 352) pol. cholera stanowi zapożyczenie z łac. cholera 'żółtaczka, żółć' (co z gr.), przejęte najprawdopodobniej za pośrednictwem śrgniem. cole$r a$. W postaci kolera słowo znane było już w epoce staropolskiej w znaczeniu 'temperament choleryczny' (SStp I: 245). W znaczeniu opisanej wyżej choroby zostało odnotowane w ESJPXVII-XVIII z najstarszym cytatem pochodzącym ze słownika Knapiusza (także w postaci kolera). Jak podaje SESł (II: 352), znaczenie to ustaliło się około połowy XIX w. (na to stulecie przypadły epidemie cholery, które objęły także Polskę - zob. Gajda 2011: 442); również w XIX w. status formy poprawnej zyskała postać cholera, funkcjonująca wcześniej obocznie do kolery.

Cholera jest jednostką ogólnogwarową (SGP IV: 12), przejętą z języka literackiego. W gwarach - podobnie jak we współczesnej polszczyźnie - leksem ten stano- 
wi komponent wielu związków frazeologicznych, funkcjonuje jako przekleństwo oraz wyzwisko, wyrazy pochodne od niego słowotwórczo (przymiotniki cholerny, cholerski, rzeczowniki cholerstwo, cholernik, cholernica - zob. SGP (IV: 13-14)) są zaś jednostkami negatywnie nacechowanymi. Nie zamieszczam tego materiału ponieważ - z pewnymi wyjątkami - nie odbiega on od tego, co znane jest we współczesnym języku polskim, poza tym można go znaleźć w wydanych już tomach SGP (IV: 12-14).

Chciałabym jednak zwrócić uwagę na tabu, którym objęte było słowo cholera w kulturze ludowej, por. np.: „Słabość - epidemija, a zwłaszcza cholera, któréj wspominać boją się. Cholery używają tylko w przekleństwach" (ok. Drohobycza (Ukraina) Zb I: 75), „O cholerze mówili śpiączka, gdyż wymienienie jej nazwy mogłoby sprowadzić chorobę” (Szychowska-Boebel 1972: 39); „Już wienc ['więcej'] jak sześdziesiont lat nie było u nas choliery, żeby choć w zło godzine nie wymówić" (Miłkowice-Maćki siem). Jak pokazują powyższe wypowiedzi, należało unikać wymawiania słowa cholera, aby nazywana przez nie choroba nie została przywołana. Użycie go w przeklęciu stanowiło zatem świadome złamanie tabu. Wiara w to, że przez wypowiedzenie tego wyrazu można sprowadzić chorobę, była zarówno powodem, dla którego w codziennej komunikacji unikano tej nazwy, jak i uzasadnieniem sięgania po nią w przeklęciach - to bowiem, co w tym pierwszym wypadku byłoby skutkiem niepożądanym - czyli pojawienie się choroby - w wypadku przeklęcia stawało się zamierzonym celem nadawcy.

Podsumowując analizę wybranej grupy przeklęć oraz zawartych w nich nazw chorób, chciałabym zaznaczyć przede wszystkim, że sięganie $\mathrm{w}$ tego rodzaju formułach po nazwy chorób epidemicznych nie jest specyfiką gwar. Przeklęcia z ich nazwami znajdziemy także w polszczyźnie ogólnej, np. bodaj, żeby cię ( $g o$, was, ich) morowe (powietrze wydusiło) (SJPD IV: 841); Bodaj was cholera wydusiła, złodzieje!; Ażeby was pomsta! ażeby was cholera...; niech ich cholera; niech ich cholera weźmie, trzaśnie; cholerę w bok (SJPD I: 890-891); niech ich (was) zaraza wydusi (SJPD X: 735). Różnica między nimi a przeklęciami gwarowymi dotyczyć może jednak nazw chorób, jakie w formułach tych występują.

Opisując funkcjonowanie danej nazwy w gwarach, starałam się pokazać, że jednostki te często są również komponentami innych frazeologizmów służących do wyrażania negatywnych emocji oraz podlegają procesom derywacji semantycznej i słowotwórczej, w których wyniku powstają jednostki pejoratywnie nacechowane (głównie pełniące funkcję wyzwisk lub określeń osób negatywnie ocenianych). Wszystkie wymienione tu procesy - neosemantyzacja, derywacja słowotwórcza, powstawanie frazeologizmów - bazują na negatywnych konotacjach związanych z nazwami chorób w ich znaczeniach podstawowych. Te właśnie konotacje motywują nowe jednostki, w których element negatywnej oceny staje się elementem definicyjnym. 
Przywoływane w tym artykule frazeologizmy z nazwami chorób (takie jak do powietrza czy idź do morówki) można traktować jako wariantywne wobec związków $\mathrm{z}$ komponentem 'diabeł' ${ }^{20}$. W ten sposób można też interpretować niektóre przeklęcia z nazwami chorób epidemicznych, głównie z czasownikiem wziać (np. Niech cie powietrze weźnie, Niech jego pomorek weźnie z tako roboto), charakterystycznym dla przeklęć z rzeczownikiem diabeł lub jego synonimami. Interpretacja taka znajduje dodatkowe uzasadnienie we właściwej kulturze ludowej tendencji do personifikowania chorób, zwłaszcza zakaźnych (zob. np. Marczewska 2012: 167-171)21.

W ramach artykułu przedstawiłam tylko jedną grupę nazw spośród tych, które najczęściej występowały w zebranym materiale. Warto jednak dodać, że to, co zostało tu powiedziane o nazwach chorób epidemicznych, zasadniczo odnosi się też do innych nazw chorób popularnych w przeklęciach (nazw febry, paralizu, kolki, szlagu). Po pierwsze, kwerenda w słownikach języka polskiego (SL, SW, SJPD) oraz NKPP wykazała, że również w polszczyźnie ogólnej te nazwy chorób były lub są używane w przeklęciach. Po drugie, mają one $\mathrm{w}$ gwarach podobny potencjał jak nazwy chorób epidemicznych - tak jak one są składnikami frazeologizmów wariantywnych w stosunku do związków z komponentem 'diabel' oraz podlegają procesom derywacji semantycznej i słowotwórczej, których rezultatem jest powstawanie jednostek nacechowanych pejoratywnie ${ }^{22}$.

\section{Skróty nazw powiatów i innych nazw geograficznych}

bial-podl - bialski (Biała Podlaska), brzoz - brzozowski, chłm - chełmski, ciesz - cieszyński, dęb - dębicki, inow - inowrocławski, iłż - iłżecki, kal - kaliski, kasz. - kaszubski, Koc Kociewie, koniń - koniński, krak - krakowski, kras - krasnostawski, Krp - Kurpie, Kuj Kujawy, łęcz - łęczycki, mław - mławski, Mp - Małopolska, myślen - myślenicki, n-tar nowotarski, opocz - opoczyński, ostroł - ostrołęcki, płoc - płocki, radz-podl - radzyński, raw-maz - rawski, rzesz - rzeszowski, siem - siemiatycki, sier - sieradzki, suw - suwalski, tarnob - tarnobrzeski, tor - toruński, tur - turecki, ukr - ukraiński, wad - wadowicki, wiel - wieluński, włod - włodawski, wys-maz - wysokomazowiecki, zam - zamojski

20 Gwarowe frazeologizmy tego typu zostały omówione w: Buława 2016.

21 W wypadku formuł $\mathrm{z}$ nazwami chorób epidemicznych taką interpretację można uznać za uzasadnioną, niemniej nie można w ten sposób traktować każdego przypadku przeklęć z czasownikiem wziąć, nie uwzględniając pozafrazeologicznych kolokacji, w jakich występuje dana nazwa (więcej na ten temat zob. Buława 2016).

22 Oczywiście stwierdzenia te odnoszą się do podanych nazw jako grupy; poszczególne nazwy $\mathrm{w}$ różnym stopniu podlegają wymienionym tutaj procesom. 


\section{Inne skróty}

br. - białoruski, cz. - czeski, dial. - dialektalny, gm. - gminny, gr. - grecki, łac. - łaciński, przest. - przestarzały, psł. - prasłowiański, ros. - rosyjski, śrgniem. - średnio-górno-niemiecki, ukr. - ukraiński

\section{Źródła}

Derd: J. Derdowski, O panu Czorlińscim, co do Pucka po sece jachoł, Toruń 1880.

DwZw: S. Dworakowski, Zwyczaje rodzinne w powiecie wysokomazowieckim, Warszawa 1935.

KąśSGO: J. Kąś, Słownik gwary orawskiej, t. 1-2, wyd. 2, Kraków 2011.

KRAK: O. Kolberg, Krakowskie, t. 1-4, Kraków 1871-1875.

KuJ: O. Kolberg, Kujawy, t. 1-2, Warszawa 1867.

LL V: A. Chętnik, Teksty ludowe. Miodobranie na Kurpiach, „Literatura Ludowa” V, z. 4-6, 1961, s. 98-108.

LL XIX: S. Bąk, Wspomnienia Anny Bąkowej, „Literatura Ludowa” XIX, z. 3, 1975, s. 32-53.

LuB: O. Kolberg, Lubelskie, t. 1-2, Kraków 1883-1884.

Lud XII: J. Sulisz, Zapiski etnograficzne z Ropczyc, „Lud. Organ Polskiego Towarzystwa Ludoznawczego" XII, 1906, s. 57-81.

ŁĘcz: O. Kolberg, Łęczyckie, Kraków 1889.

MacSŁ: J. Maciejewski, Słownik chetmińsko-dobrzyński, Toruń 1969.

ME VI: A. Saloni, Lud łańcucki. Materiały etnograficzne, „Materiały Antropologiczno-Archeologiczne i Etnograficzne" VI, 1903, s. 304.

ME IX: J. Kantor, Czarny Dunajec. Monografia etnograficzna, „Materiały Antropologiczno-Archeologiczne i Etnograficzne" IX, 1907, s. 17-229.

ME XI: O. Kolberg, Tarnów - Rzeszów. Materiały etnograficzne zebrał Oskar Kolberg, uporządkowat $i$ wydał Seweryn Udziela, „Materiały Antropologiczno-Archeologiczne i Etnograficzne" XI, 1910, s. 116-323.

MPTL XXVI: W. Gaj-Piotrowski, Kultura społeczna ludu z okolic Rozwadowa, „Prace i Materiały Etnograficzne", t. 26, Wrocław 1967.

NKJP: Narodowy Korpus Języka Polskiego, http://nkjp.pl/.

PF IV: R. Lubicz [H. Łopaciński], Przyczynki do nowego słownika języka polskiego, „Prace Filologiczne" IV, 1893, s. 173-279.

PF V: H. Łopaciński, Przyczynki do nowego słownika języka polskiego, „Prace Filologiczne" V, 1899, s. 681-976.

PJPAN 11: M. Kucała, Porównawczy słownik trzech wsi małopolskich, „Prace Językoznawcze PAN", nr 11, Wrocław 1957.

PJPAN 37, 47, 72: M. Szymczak, Słownik gwary Domaniewka w powiecie łęczyckim, cz. 2: F-J, cz. 5: O-Pś, cz. 8: Z-Ż, „Prace Językoznawcze PAN”, nr 37, 47, 72, Wrocław 1964, 1969, 1973.

PJPAN 48: H. Horodyska-Gadkowska, Polskie słownictwo gwarowe z zakresu hodowli zwierząt domowych, „Prace Językoznawcze PAN”, nr 48, Wrocław 1967. 
Pleszcz: A. Pleszczyński, Bojarzy międzyrzeccy. Studium etnograficzne, Warszawa 1892. PORJ 1956: H. Horodyska, Z gwary suwalskiej, „Poradnik Językowy” nr 2, 1956, s. 73-74. RŁTN XXVI: K. Dejna, Słownictwo ludowe z terenu byłych województw kieleckiego i łódzkiego (Pa-Por), „Rozprawy Komisji Językowej Łódzkiego Towarzystwa Naukowego” XXVI, 1980, s. 117-257.

RWF IX: J. Biela, Gwara zebrzydowska. Studium dialektologiczne, „Rozprawy i Sprawozdania z Posiedzeń Wydziału Filologicznego Akademii Umiejętności” IX, 1882, s. 149-217.

RWF XI: J. Łoś, Gwara opoczyńska. Studium dialektologiczne, „Rozprawy i Sprawozdania z Posiedzeń Wydziału Filologicznego Akademii Umiejętności” XI, 1886, s. 147-19o.

RWTN III: F. Bizoń, Ze słownictwa gwarowego na Śląsu Cieszyńskim (Etymologie), „Rozprawy Komisji Językowej Wrocławskiego Towarzystwa Naukowego” III, 1961, s. 101-126.

SGK: B. Sychta, Słownik gwar kaszubskich na tle kultury ludowej, Wrocław - Warszawa Kraków 1967-1976.

SAND: O. Kolberg, Sandomierskie, Warszawa 1865.

SKJ VD: B. Dembowski, Słownik gwary podhalskiej, „Sprawozdania Komisji Językowej Akademii Umiejętności w Krakowie" V, 1894, s. 339-444.

SKJ VG: W. Grzegorzewicz, O języku ludowym w powiecie przasnyskim, „Sprawozdania Komisji Językowej Akademii Umiejętności w Krakowie” V, 1894, s. 72-126.

SKoc: B. Sychta, Słownictwo kociewskie na tle kultury ludowej, t. I-III, Wrocław 1980-1985.

Skrz: K. Skrzyńska, Kobieta w pieśni ludowej, Warszawa 1891.

SовKuJ: Z. Sobierajski, Gwary kujawskie, Poznań 1952.

WisŁa X: K. Mátyás, Przezwiska ludowe w powiatach tarnobrzeskim, niskim i brzeskim w Galicji, „Wisła” X, 1896, s. 725-744.

WisŁA XI: A. Osipowicz, Lecznictwo ludowe. Nazwy ludowe niektórych chorób, z wymienieniem środków, używanych po wsiach na ich leczenie w dawnym Augustowskim, „Wisła” XI, 1897, s. 771-783.

WisŁa XV: A. Rumel, Pojęcia ludu o przyrodzie, „Wisła” XV, 1901, s. 8 o.

WMal: W. Malinowski, Gwara rębowska, „Biblioteczka Słuchaczy Państwowego Wyższego Kursu Nauczycielskiego w Lublinie”, nr 5, Warszawa 1925.

ZB I: P. Parylak, Prowincjonalizmy mowy polskiej w Drohobyczu i jego okolicach zestawione i porównane z językiem ruskim, staropolskim i narzeczem kaszubskim, „Zbiór Wiadomości do Antropologii Krajowej” I, Kraków 1877, s. 57-78.

Zв II: W. Sierakowski, Materiały do etnografii ludu polskiego z okolic Kielc, „Zbiór Wiadomości do Antropologii Krajowej” II, Kraków 1878, s. 209-259.

\section{Literatura}

Boryś W., 1992, Etymologie polskie: 11. dial. pomucha, „Język Polski” LXXII, s. 163-166.

BuŁawa M., 2016, Paralusz i inne „odmiany złośliwych diabłów”, czyli o związkach między choroba a diabłem we frazeologii gwarowej, [w:] M. Rak, K. Sikora (red.), Słowiańska frazeologia gwarowa, „Biblioteka LingVariów”, t. 23, Kraków, s. 229-248.

ENGELKIng A., 2010, Klątwa. Rzecz o ludowej magii słowa, wyd. II popr. i uzup., Warszawa.

ESJPXVII-XVIII: W. Gruszczyński (red.), Elektroniczny słownik języka polskiego XVII i XVIII wieku (http://sxvii.pl). 
Gajda Z., 2011, Do historii medycyny wprowadzenie, Kraków.

GDACjusz A., 1969, Wybór pism, oprac. H. Borek, J. Zaremba, Warszawa - Wrocław.

Grochowski M., 1991, Przekleństwo $i$ wulgaryzm jako kwalifikatory pragmatyczne jednostek leksykalnych, „Acta Universitatis Nicolai Copernici” „Filologia Polska” t. 36: „Nauki Humanistyczno-Społeczne" z. 230, s. 3-25.

MarCzewska M., 2012, Ja cię zamawiam, ja cię wypędzam... Choroba. Studium językowo-kulturowe, Kielce.

NKPP: J. Krzyżanowski (red.), Nowa księga przysłów i wyrażeń przysłowiowych polskich, w oparciu o dzieło Samuela Adalberga oprac. zesp. red. pod kier. J. Krzyżanowskiego, t. 1-4, Warszawa 1969-1978.

PRZYByLSKa R., 1986, Co się komu »ciśnie na usta«, czyli o pewnym typie wyrażeń ekspresywnych, „Język Polski” LXVI, s. 347-351.

PSL: F. Giedroyć, Polski słownik lekarski, t. I-II, Warszawa 1931-1933.

PSWP: H. Zgółkowa (red.), Praktyczny słownik współczesnej polszczyzny, t. 1-50, Poznań 1994-2005.

SEBAń: A. Bańkowski, Etymologiczny słownik języka polskiego, t. I-II, Warszawa 2000.

SEBor: W. Boryś, Słownik etymologiczny języka polskiego, Kraków 2005.

SESŁ: F. Sławski, Słownik etymologiczny języka polskiego, t. I-V, Kraków 1952-1982.

SGP: Słownik gwar polskich, red. M. Karaś (Źródła, t. 1), J. Reichan (t. 2-9, z. 2), S. Urbańczyk (t. 2-5), J. Okoniowa (t. 6-9, z. 2), B. Grabka (t. 7-9, z. 2), R. Kucharzyk (t. 9, z. 2), t. 1-3: Wrocław - Warszawa - Kraków 1977-1991, t. 4-9, z. 2: Kraków 1992-2015.

Sienkiewicz 1978: H. Sienkiewicz, Selim Mirza, [w:] idem, Nowele, t. 2, Warszawa 1978, s. 322-379.

SienkiewICZ 1986: H. Sienkiewicz, Listy z podróży do Ameryki, Warszawa 1986.

SJPD: W. Doroszewski (red.), Słownik języka polskiego, t. I-XI, Warszawa 1958-1969.

SJPSz: M. Szymczak (red.), Słownik jezyka polskiego, t. I-III, Warszawa 1993.

SL: S.B. Linde, Słownik języka polskiego, wyd. 2, poprawne i pomnożone, t. I-VI, Lwów 1854-1860.

SPXVI: Słownik polszczyzny XVI wieku, t. I-IV, red. komitet redakcyjny, t. V-XVII, red. M.R. Meyenowa, t. XVIII-XXXIV, red. F. Pepłowski, t. XXXV-XXXVI, red. K. Mrowcewicz, P. Potoniec, Wrocław - Warszawa - Kraków 1966-2012.

SSTP: S. Urbańczyk (red.), Słownik staropolski, t. I-XI, Wrocław - Warszawa - Kraków 1953-2002.

SW: J. Karłowicz, A.A. Kryński, W. Niedźwiedzki (red.), Słownik języka polskiego, t. I-VIII, Warszawa 1900-1927.

SWIL: A. Zdanowicz i in. (red.), Słownik języka polskiego, t. I-II, Wilno 1861.

SzychowskA-Boebel B., 1972, Lecznictwo ludowe na Kujawach (Materiały i rozważania), Toruń.

USJP: S. Dubisz (red.), Uniwersalny słownik języka polskiego, t. 1-4, Warszawa 2003.

Гр.: Грінченко Б.Д., Словарь української мови, t. 1-4, Київ 1958-1959.

ФСССГД: Ужченко В.Д., Фразеологічний словник східнослобожанських і степових говірок Донбасу, Луганськ 2013 (http://dspace.ltsu.org/jspui/bitstream/123456789/1765/1/ Ugchenko2.pdf).

ЭССЯ: О. Трубачев (red.), Этимологический словарь славянских языков. Праславянский лексический фонд, t. 1-40, Москва 1974-2016. 


\section{Names of epidemic illnesses in dialectal curses \\ Summary}

The paper is concerned with dialectal curses containing names of illnesses. Following a presentation of the units of this type that appeared in our material, a detailed analysis is given of the group of curses which use the names of epidemic illnesses: powietrze, morówka, pomór, pomorek, dżuma, pomucha (all six meaning 'plague, pest, murrain'), and cholera ('cholera'). The curses have been shown in a broader linguistic context which takes into account the functioning of the given name in dialects, not only as the base name of the illness, but also as an element of phraseological expressions and as a unit which undergoes the processes of semantic and word-formative derivation. 